\title{
The role of trade narratives in poverty reduction after the COVID-19 crisis
}

\author{
Scott Allen Hipsher \\ Webster University, Bangkok, Thailand
}

Abstract

Purpose - This paper aims to explore different possible economic narratives concerning trade, which may emerge based on lessons learned from the COVID-19 crisis and likely effects of these differing narratives would have on global poverty reduction.

Design/methodology/approach - This is a conceptual paper based on original analysis of selected literature.

Findings - The global response to the COVID-19 crisis of severely restricting international travel and business operations has been accompanied by slowing economic growth and increased levels of global poverty. Due to the nature of the crisis, it is not currently clear, even with hindsight, whether the measures taken have produced more benefits than problems. However, the pace and direction of the economic recovery and the effect on future levels of global poverty will likely depend to some extent on which narratives go viral and become accepted.

Social implications - Members of academia as well as others have a role to play in creating and spreading narratives about economic activities and focusing on narratives, which do not ignore the plight of the global poor in the aftermath of the current crisis might have a positive effect on the living standards of the hundreds of millions of people living in poverty who have been affected by the current global economic slowdown.

Originality/value - The paper uniquely links ideas associated with behavioral economics, international business theories and empirical evidence with reducing poverty as we move past the COVID-19 crisis.

Keywords Narratives, Poverty reduction, Wealth creation, Exploitation, COVID-19, UN Sustainable Development Goals, International trade

Paper type Conceptual paper

\section{Introduction: poverty reduction and COVID-19}

The UN Sustainable Development Goal most likely to be directly addressed by multinational enterprises (MNEs) and other private sector actors involved in international trade would appear to be the first goal, to eliminate extreme poverty by 2030 . Prior to the COVID-19 crisis, the world had experienced amazing success in reducing extreme poverty around the world (Mokyr, 2017, p. 3). However, the success in reducing poverty had not been evenly spread across the world and rates of poverty reduction have slowed globally in recent years (Milanovic, 2019). Moreover, when the income level used to measure poverty is

(C) Scott Allen Hipsher. Published in Review of Economics and Political Science. Published by Emerald Publishing Limited. This article is published under the Creative Commons Attribution (CC BY 4.0) licence. Anyone may reproduce, distribute, translate and create derivative works of this article (for both commercial and non-commercial purposes), subject to full attribution to the original publication and authors. The full terms of this licence maybe seen at http://creativecommons.org/licences/by/4.0/legalcode 


\section{REPS \\ 6,1}

raised, it can be seen, "nearly half the world (46\%) lives on less than US\$5.50 per day" (World Bank, 2018, p. 7).

Despite the previous success, the slowing of global economic activities due to the COVID-19 crisis has put into jeopardy the incomes of hundreds of millions of vulnerable people living below or just above official income levels used to measure extreme poverty (African Development Bank, 2020). While the full effect of the closing down of many global economic activities is difficult to determine at this time, there appears to be near unanimous agreement the pandemic is causing a decrease in global economic output and an increase in global poverty (e.g. International Monetary Fund, 2020; Morsy et al., 2020; World Bank, 2020).

Finding ways to contribute to reducing poverty in normal times is challenging, but the challenge has increased due to societies' reactions to the COVID-19 crisis. Under these circumstances, it might be accurate to classify our current situation as a "wicked problem," using the definition provided by Rittel and Webber (1973). Decision makers are having difficulties in defining the problem and reaching agreement on priorities, while the information on which decisions are being made has been changing, inconsistent, and often conflicting. "What does one recommend when what is known changes on a daily basis?" (Goldberg, 2020, p. 197). Without clear and mutually agreed upon goals and clear and consistent data, it is likely multiple narratives will emerge advocating accepting differing lessons learned and preferred ways forward.

"So far we face an economic crisis, not a financial crisis" (Wyplosz, 2020, p. 27), and it is likely, "The economic problems could persist well after the pandemic is contained" (Furman, 2020, p. 192). Yet, the rest of this article is built on the assumption, "The COVID-19 pandemic will eventually fade as a dominant issue. There will be a period of economic rebuilding based on the economic fall-out of the pandemic" (Lee, 2020, p. 6). While the introduction of vaccines has been a cause for optimism, the economic fall-out after the health crisis fades is expected to be especially hard on the poor, who often work in the informal economy in less developed countries where there are few financial safety nets (Menon, 2020).

It has often been observed, individuals and communities have been becoming more focused on protecting people closer to themselves in response to fear over the COVID-19 situation (Posen, 2020). Thus, it is possible to see concerns over global poverty frequently taking a lower priority when compared to protecting the health and economic welfare of people in one's own community and country. The plight of the world's poor might be overlooked as governments, the media and members of academia focus on local health and economic issues. It is likely to see narratives continue to emerge on health and safety approaches in the post-pandemic era, but economic narratives including narratives on trade, might be especially important in reducing poverty and assisting economic recovery.

"A major venue through which people of all the cultures of the world share information and attitudes with others in their group is in narratives" (Tomasello, 2008, p. 283). At times, commonly accepted narratives have their origins in scientific or academic research, and at other time academics tend to base their ideas and research on already accepted popular narratives (Shiller, 2019). Also, before introduction, it is difficult to predict with any degree of accuracy which narratives will be accepted, and which ones rejected. Yet, the narratives opinion leaders decide to focus on in the aftermath of the COVID-19 situation will likely influence government policies and economic activities and thus can have an effect on people living in poverty.

While the effectiveness and costs of the economic lockdowns are likely to be debated for years, the future direction of the global economy is likely to depend to a large extent on which competing narratives go "viral." Shiller (2019, 2020) made the point economic decisions made by average people often have as much or more impact on economy growth 
than decisions made by politicians and economists; and average people are likely to be more influenced in their decision-making by popular narratives, or stories, than empirical evidence. One major competing type of narrative is likely to build upon the viewpoint international trade is generally exploitative. These types of narratives are likely to explain international trade and travel, as well as greedy private sector actors, helped spread the virus and these factors are also responsible for the growing levels of inequality seen during the crisis. Another possible type of narrative could involve the idea curtailing of international trade and travel and the activities of private sector actors in response to public safety concerns have caused a major reduction of economic opportunities. Therefore, it is advisable to remove barriers to international trade and travel and other economic activities as soon as possible to create more opportunities, especially to help lessen the hardships the current measures have imposed on the world's least prosperous citizens.

\section{Methodology}

A conceptual approach was chosen and based on Shiller's (2019) framework of narratives founded on principles associated with behavior economics. A review of selected literature was used to frame the discussion and due to the nature of the topic and the lack of complete or reliable data taking a more empirical approach would be inappropriate at this time.

Narratives promoting both pro and anti-business viewpoints often compete, and there seems to be a cycle where at times pro-business and pro-trade narratives are more prominent and other times anti-business and anti-trade sentiments have more influence (Shiller, 2019, pp. 239-257). Both general types of narratives are examined and the effects that acceptance of either types of narratives is likely to have on people currently living in or in danger of falling into extreme poverty.

\section{International trade: exploitation versus creation of opportunity narratives \\ 3.1 Trade as exploitation narratives}

Scholars, such as Mason (2019), Okokhere (2018) and Wallerstein (2013), have promoted narratives claiming business and international trade are basically exploitative in nature while tending to focus on the negative aspects of modern society, such as income inequalities, the fact some people continue to live in poverty and global warning. Scholars with these viewpoints often attribute most of these negative aspects of modern life with markets and activities of the private sector. For example, Banerjee and Duflo (2019) in the preface to their book, Good Economics for Hard Times (the hard times referred to the preCOVID-19 era), made assumptions of the negative aspects in modern life. There assumptions were reflected in the asking of the questions, how can the world "be put back together" and "what went wrong and why?" These questions illustrate narratives about the negative nature of modern life prior to the COVID-19 pandemic. There are many narratives written with the underlying assumption the current global state of affairs is mostly negative and primarily caused by actors involved in business and international trade, for further examples see Burmester et al. (2019), Cohen (2020) and Khalidi (2018).

The profit motive has often been associated with narratives involving greed, fraud, deceit and selfish intentions. Marxist political narratives tend to be based on the beliefs markets and the wealthy exploit the poor and a business' profits come at the expense of the workers (e.g. Becker, 1998; Bushan, 2016; Dikotter, 2016). In addition, the most common narratives found in most of the world's religious traditions take a negative view of the profit motive driving international trade (e.g. Hipsher, 2010; Rosen, 1982; Yarbrough, 2016). Moreover, many influential philosophic traditions are also based on narratives which express opposition to placing an emphasis on seeking material possessions (e.g. Graafland, 2009; 


\section{REPS \\ 6,1}

Krier and Worrell, 2017; Rangan, 2018). Therefore, narratives focusing on negative aspects of life and the evils of businesses and trade have been and still are very influential and have an impact on policies and practices which affect people living in poverty.

Some narratives presented in more developed economics often attribute growing income inequality to a large extent on international trade, for examples, see Piketty (2014) and Rodrik (2018). Yet, income inequality has been common throughout history (Scheidel, 2017), and it is generally higher in nations with relatively lower levels of trade and less democratic political systems (e.g. Fosu, 2017; Miller et al., 2019; Stifel and Woldehanna, 2016). Additionally, primarily due to increased incomes in Asia, income inequality has not been rising in recent decades when looked at from a global perspective (e.g. Dabla-Norris et al., 2015; Dollar et al., 2014; Milanovic, 2013, 2016, 2017, 2019). Narratives promoting income inequality within one's own country might become more prominent in the public's attention in Western countries in recent years often crowding out concerns over global poverty.

Some narratives which often make the rounds, are based on claims officials in governments in developing or less developed countries do not have the inclination or ability to protect workers or consumers from exploitation from greedy and sophisticated executives from MNEs such as seen in Fasterling and Demuijnck (2013) and Kobrin (2009). Therefore, it has been proposed by scholars, such as Bijlmakers (2013) and Siddiqui and Uddin (2016), the UN or other international organizations create and enforce a legal framework to protect workers in developing or less developed economies. While other writers, such as Bonfandi (2015) and Bernaz (2013), have used a variation of this type of narrative to advocate MNEs having legal liability in a developed country for operations in developing or less developed economies. Although these types of proposals can be perceived as advocating the reduction of the political sovereignty of developing or less developed nations by imposing foreign oversight and thus can be perceived as a form of cultural imperialism (Duncan, 2000). Also, having external as well as internal legal liabilities have been shown to discourage foreign investment in developing and less developed economies (Carson, 2015; Graham and Stroup, 2016). In the post pandemic environment, these types of narratives expressing the need for international oversight to reduce exploitation in developing and less developed economies could have the effect of reducing levels of international trade and slowing efforts at reducing poverty.

In recent years, there has been an increase in the support for government policies based on narratives associated with mercantilism and economic nationalism in Western countries (e.g. Boddewyn and Rittig, 2017; Collinson, 2017; O'Rourke, 2018). These narratives are often founded on the assumption workers in developed countries need to be protected from being exploited due to competition from lower paid workers in developing and less developed economies. Individuals promoting restrictions on trade based on an economic nationalistic viewpoint often claim trade within national borders has a mostly positive effect, while trade across national borders is more likely to be harmful. Advocates of mercantilism and economic nationalistic polices tend to use narratives claiming the global economy is a zerosum game between nation-states and promote helping "us" even if it is at the expense of "them." "The appeal of economic nationalism is strong when a country passes through economic hardship and when nationalistic sentiments, rather than rational thinking, drive large segments of the population" (Ali, 2017, p. 93). And most countries are currently passing through periods of economic hardship.

Frequently the narratives used for justification for supporting policies which exclude people in the least developed regions from global trade is the desire to prevent individuals living in poverty making choices which are believed to be harmful, or a desire for "native" people and their unique cultures to remained unspoiled by avoiding contact with modern or 
capitalist societies, for example, see Karnani (2010), Hall et al. (2015) and Smith (2015). People using narratives claiming business is mostly exploitative, frequently take a paternalistic view toward people living in poverty, who are considered powerless and in need of rescue by individuals from the outside. Many of these narratives found in print are "written by political scientists and human rights activists. They are mostly anecdotal in nature with normative prescriptions that are critical of business in general, if not outright anti-business" (Li and Gaur, 2014, p. 15). These types of narratives frequently do not take into account the desires and ability of people living in or close to poverty to make their own decisions when presented with new opportunities (Hipsher, 2018).

The narratives often spread in developed compared to developing and less developed economies about the exploitative nature of international trade have some similarities and some differences. The similarities focus on the negative aspects of modern life and often express the idea trade and the desire for profits are responsible for these negative aspects. However, the narratives often differ in making assumptions about who is being exploited. In more economically developed countries, the stories frequently make claims it is the lower skilled workers in the wealthier countries, who would be considered fairly wealthy by global standards (Milanovic, 2016), who are harmed. While in less economically developed countries, claims frequently focus on the negative effect on local economies due to the wealth gained by businesses originating in wealthier locations.

It has been pointed out narratives based on anti-globalization/anti-international trade sentiments or economic nationalistic ideologies are usually expressions of different forms of political populism and tend to be based more on emotional appeals than on empirical evidence (Cox, 2017). Populist rhetoric and narratives rarely have a solid theoretic foundation and are used by both the political left and right to attack members of outgroups and blame scapegoats for current problems. The actual economic populist policies based on mercantilist, isolationist and protectionist principles associated with both anti-globalization or economic nationalism have a terrible track record of producing economic growth and reductions in poverty. However, these types of narratives often have intuitive appeal to many individuals and are often used by politicians to win public support (Feldman, 2013; Helbling et al., 2016; Hoekman and Nelson, 2018).

\subsection{Trade as opportunity narratives}

Individuals, such as Bhagwati and Panagariya (2013), Cochrane (2016) and Lal (2013), spreading trade as opportunity narratives, tend to focus on the positive aspects of life in modern societies, the amazing success the world has experienced in recent decades in improving the standards of living of billions of people, and the strong correlation between international trade and poverty reduction and prosperity. For example:

"Between 1991 and 2015, the world experienced a significant decline in the share of the working poor and a noticeable fall in the share of vulnerable employment, and this occurred during a period of rapid globalization, including increased trade and lower barriers to trade" (Vandenberg, 2017, p. 2).

The empirical evidence shows the correlation is extremely strong between amount of trade and openness to trade with increased economic growth, reductions in poverty and improvements in other measurable aspect of quality of life such as life expectancy, selfreported measures of happiness, gender equality and many health issues within a society (Gwartney et al., 2018; Miller et al., 2019; Son, 2010).

Trade as opportunity narratives tend to focus on the voluntary nature of trade as opposed to the coercive nature of government regulations as seen in Hipsher (2018),
Role of trade narratives 


\section{REPS \\ 6,1}

Powell (1994) and Sowell (2015). These trade as opportunity narratives often are based on claims a person has the freedom to walk away from any private sector exchange, whether domestic or international, and whether a purchase or employment offer, the person feels is not beneficial, and the more options available, the more effective a person can make choices which will maximize one's utility. On the other hand, all government regulations are backed up by the government's monopoly on the use of force. It has been argued in these types of narratives, free markets and what is sometimes labelled as capitalism, has more to do with expanding freedom of choice than it does with enriching the few at the expense of the many. It has been argued in an efficient market enrichment of the producer can only come from the producing of goods and services consumers consider to be valuable and voluntarily choose to purchase (Gilder, 2012; Hayak,2016/1960; Hipsher, 2006).

Most of these trade as opportunity types of narratives do not include claims free markets and global trade have eliminated all poverty, inequality or global suffering. But these types of narratives tend to promote the idea the extension of international trade and the reliance on markets to organize economies has been accompanied by amazing reductions in poverty, extensions of life expectancies and improvements in most measurable aspect of quality of life. Ravallion (2016, p. 508) found, in most cases, trade leads to global wage convergence which is good for the poor, as evidenced by the large increases in average wages in both India and China in recent years (International Labour Organization, 2016). An alternative to focusing on inequality of income is a narrative, which focuses on inequities of opportunity. It has been reported much of the global income inequalities are due to the great disparities in educational or livelihood opportunities, and international trade and openness tend to increase equality of opportunities for education, employment and skill development (Hipsher, 2018, 2019, 2020).

Individuals accepting trade as opportunity narratives often believe people in developing and less developed economies, including those living in poverty, deserve the same right to make choices in regards employment and purchases as do people who were fortunate enough to be born in more prosperous circumstances (e.g. Collier, 2007; Easterly, 2013; Prahalad, 2005). The attractiveness of an economic opportunity, such as a job offer, depends on the alternatives available. What is called an exploitative "sweat shop" job in a narrative from the perspective of a person with a solid education and living in a relatively wealthy country can seem like the best opportunity to escape poverty for an individual with fewer options (Hipsher, 2018; Powell, 2014; Sachs, 2005, p. 11). Firms, whether domestic or foreign, compete for employees as well as customers, and it has been found in developing and less developed economies foreign firms on average pay higher wages and provide better working conditions than do domestic firms (e.g. Dihel et al., 2017; Hipsher, 2019; Milanovic, 2016, pp. 150-151). According to these types of narratives, removing options for employment which come from increased levels of trade will force employees to settle for less desirable ways to make a living and less valuable products to purchase.

It has often been advocated in trade as opportunity narratives to include the least prosperous citizens of the world into global trading networks as opposed to excluding them. Sen (2002) argued against:

[...] "withholding from them [people living in poverty] the great advantages of contemporary technology, the well-established efficiency of international trade and exchange and the social as well as economic merits of living in open rather than closed societies" (p. 12).

Verbecke et al. (2018) reported strict exploitation is nearly always impossible for foreign firms operating in developing and less developed economic as international firms need to combine their resources and abilities with local resources to create value. The authors also believed, "the world needs more - not - less globalization to reap the efficiencies of novel 
resource combination processes" (p. 1110). The fastest movement of millions of people out of poverty happened during the latter part of the last century in China, and this movement of hundreds of millions of people out of extreme poverty happened after the country made significant market-based reforms and the government began allowing its citizens and companies to engage in international trade; and the largest reductions in poverty happened before the government had initiated any official programs specifically targeting poverty reduction (Yan, 2016). Srinivasan (2013) compared China's experience of reducing poverty with that of India. Both countries followed a path of being engaged in limited levels of global trade in the 1950s based on the belief coming from narratives that international trade leads to exploitation and increases in poverty. In 1981, the poverty rate in India was significantly lower than the rate in China. But officials in China made dramatic economic reforms and the level of international trade has grown substantially and the standards of living have greatly improved. The officials in India chose a different path based on lessons found in different narratives and made fewer market-based reforms and the level of international trade has remained low. Today, the poverty rate is multiple times higher in India than in China. It is speculated there would be millions fewer Indians living in extreme poverty if Indian citizens and companies had been allowed to engage more freely in trade, both domestically and internationally.

Empirical evidence shows firms and individuals involved in international trade tend to see more improvements in productivity than do firms that operate only domestically (Grover-Goswami et al., 2019). Despite narratives promoting the idea trade is exploitative in nature, there is little evidence to support the view international trade results in increased levels of poverty and hardship. Verbecke et al. (2018) felt many critics of globalization were likely to engage in "xenophobic attacks on foreign trade and investment partners" and "voice concerns over growing within country inequality, while also claiming globalization leads to a decline in public goods and harm to the environment" (p. 1101). The authors went on to express the opinion, "increased globalization results in net-efficiency gains" but "unfortunately, in popular narratives, globalization has been associated with a new geography of discontent - mostly devoid of a factual basis" (p. 1102).

\section{Corporate social responsibility}

Narratives drive behaviors of members of the general public, political leaders and owners and managers of private sector firms. Narratives influencing the actions of the leaders of many firms is the expectation a firm has the responsibility to make an effort to improve society through what is often labelled as corporate social responsibility (CSR) activities (Minefee et al., 2015). While the term CSR is often used in a very abstract manner, Korontzis (2013, p. 301) claimed the term CSR was normally used to refer to voluntarily engaging in activities which will benefit various stakeholders and society in general even if the activities are not intended to maximize profits.

The most used framework to explore a company's CSR activities is the pyramid of social responsibility, consisting of four levels, economic, legal, ethical and discretionary activities, introduced by Carroll $(1974,1979,1991)$. The assumptions associated with this framework are the firm's primary responsibilities are to be economically sustainable and obey the laws of the area where it operates. These are followed by the responsibility to act in an ethical manner, and if the firm is profitable, it should try to use some of its profits to make the world a better place through discretionary activities. However, many popular CSR narratives ignore a firm's economic responsibilities and the benefits to society which come from profitable operations, such as providing employment, taxes, goods and services valued by
Role of trade narratives

65 


\section{REPS \\ 6,1}

customers, and general economic growth, and focus on actions which are specifically intended to help others but are not directly designed to improve profitability.

In Carroll's framework, acting ethically is considered going beyond merely obeying the law. Acting ethically is concerned with doing the right thing, and while doing the right thing is being examined at an abstract level, agreement can be found, when getting down to specifics, there are frequently considerable differences of opinions. Each person's ideas of right and wrong are influenced by a variety of personal, economic and cultural factors (e.g. Borges et al., 2018; Clark et al., 2018; Yang and Liu, 2018). Therefore, it is nearly impossible to, among a diverse population of stakeholders, reach consensus on selecting narratives on which to base all attempts to create ethical practices.

For-profit firms specialize in creating products and services members of society find of value and engage in voluntary exchanges to acquire. But a limited number of firms become hugely successful and control large quantities of resources. Therefore, some individuals believe these successful firms have a responsibility to use their resources to try to make the world a better place through discretionary activities. And a narrative could easily be created stating this duty is especially important during this time of global crisis. But Orlitzky (2015) questioned the wisdom of accepting narratives which make assumptions the management of for-profits firms have the ability or responsibility to make decisions on what social causes to support. Friedman's (1970), who's views have often been misrepresented as opposing all charity and social causes, believed actions intending to improve conditions were important in a well-functioning society. But in Friedman's narrative, executives of firms had neither the right nor the ability to effectively use the resources owned by other shareholders to support causes and organizations preferred by the executives. Instead, it was suggested, the money earned by the company be given back to the owners who can decide for themselves what charities or causes, if any, they wish to support. The Bill and Melinda Gates Foundation, which is a totally separate entity from Microsoft, would appear to be following the narratives of Friedman.

Evidence shows the creation of wealth, economic growth and value in a community is a necessary condition to reduce poverty and, "the firm is the main creator of value added and the ultimate driver of growth" (Cusolito and Maloney, 2018, p. xxiv). While every case of sustained and substantial reductions of poverty has been accompanied by a dynamic and profitable private sector, this is not always acknowledged in popular narratives and "the vast majority of academic studies on poverty (over 90\%) do not consider the role of multinationals and international business in poverty alleviation” (Kolk et al., 2018, p. 96). Most narratives on CSR activities are based on a belief CSR programs should be designed to directly improve society and are not focused on the indirect but often powerful and positive effects upon communities which come from operating a business in a sustainable and profitable manner.

\subsection{Wealth creation approach to corporate social responsibility}

Most of the UN's Sustainable Development Goals would not appear to be able to be directly addressed by normal activities carried out by MNEs or other private sector actors, except the goal to reduce global poverty. In many narratives, poverty reduction actions are thought of primarily as activities to redistribute resources from the wealthy to the poor, for examples, see Duflo and Banerjee (2011), Resnick and van de Walle (2013) and Sachs (2005). However, as the empirical evidence shows the correlation between economic growth and private sector activities with reductions in poverty is extremely strong (e.g. Gwartney et al., 2018; Kobrin, 2019; Miller et al., 2019). An alternative narrative, the wealth creation approach, where firms are encouraged to engage in business activities in regions of the 
world where poverty is widespread, might be especially appropriate for use in CSR programs in attempts to reduce extreme poverty in the post pandemic environment (Hipsher, 2016, 2018, 2020). It has been found, "Greater access to markets, and not more aid and assistance targeted at development, is the best means of permanently lifting the poorest people from the lowest depths of poverty" (Coyne, 2013, p. 25).

In most narratives, poverty is thought of as a lack of material possession, but it can also be thought of as a lack of opportunities. Private sector actors engaging in international trade can provide both purchasing and livelihood options which people can voluntarily chose to take advantage of or ignore. A person does not have the option to turn down a "sweatshop" or other job considered exploitative if the job is not available. Policies and practices based on narratives associating international business with exploitation often discourage firms from engaging in business in locations where poverty is widespread (Reuter et al., 2010). Doing business in the least economically developed regions of the world where most people living in extreme poverty are located is difficult. Most often, there are few suppliers, the purchasing power of consumers is low, the skills of the workforce are limited, and excessive business regulations and corruption can be serious obstacles (Grover-Goswami et al., 2019). The easiest course of action is to just ignore doing businesses in the regions of the world were poverty is widespread to avoid accusations of exploitation or being associated with narratives about cooperating with authoritarian or corrupt political regimes. The potential financial gains are often considered too small to take on the substantial risks to a firm's reputation which can come from narratives, which go viral claiming a specific company's business practices in an area where poverty is widespread are exploitative. Thus, many individuals are denied economic opportunities due to being citizens of countries which are both economically underdeveloped and having political systems, which are considered inferior, in some narratives, in comparison to the liberal democratic countries from where most MNEs and many critics of international business and trade originate.

An alternative to the narratives that CSR should focus on redistribution of wealth is to base CSR practices on ideas found in the wealth creation approach where people living in poverty are thought of as being fundamentally similar to people elsewhere, except they have fewer economic opportunities. While redistribution of wealth has its uses, especially in providing short-term help in the middle and aftermath of crises caused by natural disasters, financial crises or during the current COVID-19 situation, in the long term, using practices and promoting narratives based on the wealth creation approach is argued the best way for businesses to tackle the problem of poverty. Moves toward accomplishing The UN Sustainable Development Goal of reducing global poverty can happen by providing people who currently have the fewest economic options more opportunities and then respect their right to make choices which fit their preferred lifestyles and individual ambitions.

Yunus and Weber (2007) felt "business - the most financially innovative and efficient sector of all - has no direct mechanism to apply its practices to the goal of eliminating poverty" (p. xiv). However, businesses might be the most effective means to reduce poverty even if it is through indirect mechanisms. There is little evidence showing specific CSR discretionary activities carried out by MNEs create significant improvement in the living standards of people in less developed economies (Latif and Sajjad, 2018). Alternatively, it has been argued the best way for businesses to reduce poverty is through conducting profitable and responsible operations and thus increase economic opportunities and overall economic growth in regions where people are in need (Hofman, 2008). Promoting and spreading narratives expressing ideas that business activities help the poor, not hurt them, would likely contribute to increased investment and business activities in the least economically developed regions of the world thus contributing to reducing global poverty. 


\section{REPS \\ 6,1}

68

\section{Lessons learned and recommendations}

The lessons individuals and societies will take from and the narratives which are likely to go viral after the COVID-19 crisis might depend to a substantial extent on underlying assumptions. Individuals inclined toward supporting economic nationalism might create narratives on the dangers of the reliance of firms on global value chains. Posen (2020) warned, "Economic nationalism is an opportunistic infection, seizing its moment now when the global economy is already weakened by the COVID-19 pandemic" (p. 203). Wei (2020), in looking at our current crisis reported, "While the risk of an economic recession often tempts countries to raise trade barriers, the exact opposite is needed to boost global output and employment" (p. 76). Looking at the consequences of the current practices of curtailing global trade and putting heavy restrictions on the activities of private sector business during this crisis, it would seem difficult to make a narrative based on empirical evidence showing lowering levels of global trade and heavily controlling the activities of private enterprises once the crisis has passed will either help workers in developed countries to see increased wages or allow people currently living in poverty to find paths to increased prosperity and a higher standard of living. But popular economic narratives are not always based on empirical evidence or economic theories (Shiller, 2019). Therefore, we can expect to see competing narratives, and the more trade as opportunity narratives created and disseminated the more likely they are to spread and help in encouraging policies and practices which will help people find opportunities to lift themselves out of dire poverty.

There are many suggestions for political and macroeconomic approaches to the pandemic. A commonly expressed opinion is health concerns should take priority over economic ones (e.g. Alesina and Giavazzi, 2020; Furman, 2020; Gopinath, 2020); although it has also been pointed out concerns over economic and health issues are not always mutually exclusive (Bofinger et al., 2020; Gourinchas, 2020). There is a common narrative calling on governments to increase spending to prevent hardships for people based on a Keynesian view of economies (e.g. Galí, 2020; Gopinath, 2020; Krugman, 2020); but there are limitations to the ability of governments, especially those in less developed economies, to support people for extended periods of time (e.g. Anderson, 2020; Menon, 2020; Wyplosz, 2020). And, as pointed out by Garicano (2020), following policies based on narratives coming from previous experience with economic slowdowns assuming lack of demand is the main cause of the problem may not be useful when the goal of governments during the current crisis is to slow or reduce economic activities.

However, there have not been as many narratives created making recommendations for the strategies of MNEs and private sector actors to contribute to poverty reduction during and after the COVID-19 crisis. Currently, many firms are concentrating efforts on survival during the current unprecedented downturn in global trade. One of the biggest dangers to the global economy in the long-term is normally successful and productive firms will face liquidity problems and go bankrupt (Odendahl and Springford, 2020); the direct impact on the economy in the short term is likely to come from a large fall in consumption while the indirect impact of raising levels of unemployment and declining levels of productivity are difficult to predict, but are likely to have a larger and longer lasting negative effect on the global economy (Galí, 2020). The length and strength of the lasting negative effect on opportunities for people living in poverty is likely to depend to a large extent on which popular narratives become accepted.

For-profit businesses and MNEs are not created to directly address social issues or reduce poverty. Yet the indirect effects of business activities, even when driven solely by the desire for profits, have proven to be the most effective tools societies have in reducing poverty and achieving the other benefits which come from higher standards of living. It has 
been proposed, MNEs and other private sector actors could achieve even better results if poverty reduction through creating wealth and increased economic opportunities were strategic goals found in their CSR programs (Hipsher, 2016, 2020). Making a conscious effort to seek business opportunities in regions of the world where poverty is widespread and where there are currently few economic opportunities might be an effective CSR objective, if accepted as being ethical by the general public. A narrative where it is believed the objectives to engage in profitable as well as ethical and discretionary activities are not mutually exclusive might be helpful in creating an environment conducive to helping people move out of poverty. Also, MNEs and other private sector actors are more likely to engage in discretionary activities in communities where they are actively engaged. Thus, by engaging in business activities in regions where poverty is widespread, it is more likely a firm will try to directly improve the lives of people in the local community as well as providing all the indirect benefits which come from operating both profitability and ethically.

Currently, creating sustainable and profitable business operations in areas of the world where extreme poverty affects many people is difficult, and firms are more likely to be vilified based on values found in current narratives for their attempts than applauded. Therefore, firms often take the path of least resistance and primarily engage in charitable activities in their CSR programs to show there are being socially responsible. But, "Charity is no substitute for opportunity" (Bovard, 1994, p. 270). Setting as a goal the establishment of sustainable and ethical business operations in regions where poverty is widespread, while not abandoning the goal of making profits, could be an integral part of a company's effective CSR program which could help in achieving the primary UN Sustainable Development Goal of reducing poverty. MNEs and other private sector actors operating internationally cannot be expected to solve all the world's problems. Governments, religious institutions, medial facilities, educational institutions, museums, art galleries and other non-profit organizations are important players in improving the lives of people around the world. But MNEs and other private sector actors have a vital role in creating the wealth a society needs to pay for the other activities. Creating and spreading narratives where MNEs and other private sector actors are asked to use the wealth creation approach by using their innovative abilities and other capacities to engage in sustainable business activities in the regions where poverty is widespread, often as part of their CSR programs, can encourage firms to concentrate on what they do best for societies, which is create jobs, desired products and services and economic growth.

\section{References}

African Development Bank (2020), African Economic Outlook 2020: Supplement amid COVID-19, African Development Bank.

Alesina, A. and Giavazzi, F. (2020), "The EU must support the member at the centre of the COVID-19 crisis", in Baldwin, R. and Weder di Mauro, B. (Eds), Mitigating the COVID Economic Crisis: Act Fast and Do Whatever It Takes, CEPR Press, London, pp. 51-55.

Ali, A.J. (2017), "Economic nationalism: philosophical foundation”, Journal of Competitiveness Studies, Vol. 5 No. 2, pp. 90-99.

Anderson, J. (2020), “China's changing economic priorities and the impact of COVID-19”, in Baldwin, R. and Weder di Mauro, B. (Eds), Mitigating the COVID Economic Crisis: Act Fast and Do Whatever It Takes, CEPR Press, London, pp. 93-101.

Banerjee, A.V. and Duflo, E. (2019), Good Economics for Hard Times, Public Affairs, New York, NY.

Becker, E. (1998), When the War Was Over: Cambodia and the Khmer Rouge Revolution, Public Affairs, New York, NY.
Role of trade narratives 
REPS

6,1

Bernaz, N. (2013), "Enhancing corporate accountability for human rights violations: is extraterritoriality the magic potion?", Journal of Business Ethics, Vol. 117 No. 3, pp. 493-511, doi: 10.1007/s10551-012-1531-z.

Bhagwati, J. and Panagariya, A. (2013), Why Growth Matters: How Economic Growth in India Reduced Poverty and the Lessons for Other Developing Economies, Public Affairs, New York, NY.

Bijlmakers, S. (2013), "Business and human rights governance and democratic legitimacy: the UN 'protect, respect and remedy' framework and the guiding principles", Innovation: The European Journal of Social Science Research, Vol. 26 No. 3, pp. 288-301, doi: 10.1080/ 13511610.2013.771894.

Boddewyn, J.J. and Rittig, D. (2017), "How to regain legitimacy and relevance in a new era for international business: if not us, who?", Academy of International Business Insights, Vol. 17 No. 2, pp. 3-6.

Bofinger, P., Dullien, S., Felbermayr, G., Fuest, C., Hüther, M., Südekum, J. and Weder di Mauro, B. (2020), "Economic implications of the COVID-19 crisis for Germany and economic policy measures", in Baldwin, R. and Weder di Mauro, B. (Eds), Mitigating the COVID Economic Crisis: Act Fast and Do Whatever It Takes, CEPR Press, London, pp. 167-177.

Bonfandi, A. (2015), "Accountability in multinational corporations for human rights and environmental abuse: how far can extraterritoriality jurisdiction go?", in Sampford, C. and Zifcak, S. (Eds), Rethinking International Law and Justice, Ashgate, Farnham, pp. 151-171.

Borges, M.L., Anholon, R., Cooper, R.E., Ordoñez, Q., Santa-Eulalia, L.A. and Filho, W. (2018), "Corporate social responsibility (CSR) practices developed by Brazilian companies: an exploratory study", International Journal of Sustainable Development and World Ecology, Vol. 25 No. 6, pp. 509-517, doi: 10.1080/13504509.2017.1416700.

Bovard, J. (1994), “The World Bank and the impoverishment of nations”, in Bandow, D. and Vasquez, I. (Eds), Perpetuating Poverty: The World Bank, the IMF, and the Developing World, Cato Institute, Washington, DC, pp. 59-74.

Burmester, B., Michailova, S. and Stringer, C. (2019), "Modern slavery and international business scholarship: the governance nexus", Critical Perspectives on International Business, Vol. 15 Nos 2/3, pp. 139-157, doi: 10.1108/cpoib-02-2019-0011.

Bushan, R. (2016), Maoism in India and Nepal, Routledge, New York, NY.

Carroll, A.B. (1974), "Corporate social responsibility: its managerial impact and implications”, Journal of Business Research, Vol. 2 No. 1, pp. 75-88, doi: 10.1016/S0148-2963(74)80008-1.

Carroll, A.B. (1979), “A three-dimensional model of corporate performance”, The Academy of Management Review, Vol. 4 No. 4, pp. 497-505, doi: 10.2307/257850.

Carroll, A.B. (1991), "The pyramid of corporate social responsibility: toward the moral management of organizational stakeholders", Business Horizons, Vol. 34 No. 4, pp. 39-48, doi: 10.1016/0007-6813 (91)90005-G.

Carson, L.D. (2015), "Laws of unintended consequences: the impacts of antiforeign bribery laws on developing countries", Doctoral Dissertation, University of Toronto.

Clark, D., Li, D. and Shepard, D.A. (2018), "Country familiarity in the initial stage of foreign market selection”, Journal of International Business Studies, Vol. 49 No. 4, pp. 442-472, doi: 10.1057/s41267-017-0099-3.

Cochrane, J.H. (2016), “Trade and immigration”, in Shultz, G. (Ed.), Blueprint for America, Hoover Press, Stanford, CA, pp. 109-125.

Cohen, R. (2020), Impact: Reshaping Capitalism to Drive Real Change, Random House.

Collier, P. (2007), The Bottom Billion: Why the Poorest Countries Are Failing and What Can Be Done about It, Oxford University Press.

Collinson, S. (2017), "The declining relevance and legitimacy of IB scholarship in a world that really needs it", Academy of International Business Insights, Vol. 17 No. 2, pp. 7-10. 
Cox, M. (2017), "Farewell to globalization: farewell to the liberal world order? The populist revolt from Brexit to Trump and beyond", London School of Economics Public Lecture Series, Podcast available from lse.ac.uk.

Coyne, C.J. (2013), Doing Bad by Doing Good: Why Humanitarian Action Fails, Stanford University Press.

Cusolito, A.P. and Maloney, W.F. (2018), Productivity Revisited: Shifting Paradigms in Analysis and Policy, World Bank, Washington, DC.

Dabla-Norris, E. Kochhar, K. Suphaphiphat, N. Ricka, F. and Tsounta, E. (2015), "Causes and consequences of income inequality: a global perspective", International Monetary Fund (IMF) Working Paper, SDN/15/13.

Dihel, N., Goswami, A.G., Hollweg, C., Shahid, S. and Slany, A. (2017), "How does participation in international value chains matter to African farmers?", in Keane, J. and Baimbill-Johnson, R. (Eds), Future Fragmentation Processes: Effectively Engaging with the Ascendancy of Global Value Chains, Commonwealth Secretariat, London, pp. 87-93.

Dikotter, F. (2016), The Cultural Revolution: A People's History 1962-1976, Bloomsbury Publishing, London.

Dollar, D. Kleineberg, T. and Kraay, A. (2014), "Growth, inequality, and social welfare: cross country evidence”, World Bank Policy Research Working Paper, WPS 6842.

Duflo, E. and Banerjee, A.V. (2011), Poor Economics: A Radical Rethinking of the Way to Fight Global Poverty, Public Affairs, New York, NY.

Duncan, C.J. (2000), "The 1998 foreign corrupt practices act amendments: moral empiricism or moral imperialism?", Asian-Pacific Law and Policy Journal, Vol. 16, pp. 1-47.

Easterly, W. (2013), The Tyranny of Experts: Economists, Dictators and the Forgotten Right of the Poor, Basic Books, New York, NY.

Fasterling, B. and Demuijnck, G. (2013), "Human rights in the void? Due diligence in the UN guiding principles on business and human rights", Journal of Business Ethics, Vol. 116 No. 4, pp. 799-814, doi: 10.1007/s10551-013-1822-z.

Feldman, S. (2013), "Political ideology", in Huddy, L., Sears, D.O. and Levy, J.S. (Eds), The Oxford Handbook of Political Psychology, 2nd ed., Oxford University Press, pp. 591-626.

Fosu, A.K. (2017), "Growth, inequality, and poverty reduction: Africa in a global setting", in Nissanke, M. and Ndulo, M. (Eds), Poverty Reduction in the Course of African Development, Oxford University Press, pp. 57-76.

Friedman, M. (1970), "The social responsibility of business is to increase its profits", The New York Times Magazine.

Furman, J. (2020), "Protecting people now, helping the economy rebound later", in Baldwin, R. and Weder di Mauro, B. (Eds), Mitigating the COVID Economic Crisis: Act Fast and Do Whatever It Takes, CEPR Press, London, pp. 191-196.

Galí, J. (2020), "Helicopter money: the time is now", in Baldwin, R. and Weder di Mauro, B. (Eds), Mitigating the COVID Economic Crisis: Act Fast and Do Whatever It Takes, CEPR Press, London, pp. 57-61.

Garicano, L. (2020), “The COVID-19 bazooka for jobs in Europe”, in Baldwin, R. and Weder di Mauro, B. (Eds), Mitigating the COVID Economic Crisis: Act Fast and Do Whatever It Takes, CEPR Press, London, pp. 129-138.

Gilder, G. (2012), Wealth and Poverty: A New Edition for the Twenty-First Century, Regnery Publishing, Washington, DC.

Goldberg, P. (2020), "Policy in the time of coronavirus", in Baldwin, R. and Weder di Mauro, B. (Eds), Mitigating the COVID Economic Crisis: Act Fast and Do Whatever It Takes, CEPR Press, London, pp. 197-201.

Gopinath, G. (2020), "Limiting the economic fallout of the coronavirus with large targeted policies", in Baldwin, R. and Weder di Mauro, B. (Eds), Mitigating the COVID Economic Crisis: Act Fast and Do Whatever It Takes, CEPR Press, London, pp. 41-47. 


\section{REPS \\ 6,1}

Gourinchas, P.O. (2020), "Flattening the pandemic and recession curves", in Baldwin, R. and Weder di Mauro, B. (Eds), Mitigating the COVID Economic Crisis: Act Fast and Do Whatever It Takes, CEPR Press, London, pp. 32-39.

Graafland, J.J. (2009), "Do markets crowd out virtues? An Aristotelian framework”, Journal of Business Ethics, Vol. 91 No. 1, pp. 1-19, doi: 10.1007/s10551-009-0072-6.

Graham, B. and Stroup, C. (2016), "Does anti-bribery enforcement deter foreign investment?", Applied Economics Letters, Vol. 23 No. 1, pp. 63-67, doi: 10.1080/13504851.2015.1049333.

Grover-Goswami, A., Medvedev, D. and Olafsen, E. (2019), High-Growth Firms: Facts, Fiction, and Policy Options for Emerging Economies, World Bank, Washington, DC.

Gwartney, J., Lawson, R., Hall, J. and Murphy, R. (2018), Economic Freedom of the World: 2018 Annual Report, Frazier Institute, Vancouver.

Hall, C.M., Gossling, S. and Scott, D. (Eds) (2015), "Tourism and sustainability: an introduction”, The Routledge Handbook of Tourism and Sustainability, Routledge, London, pp. 1-12.

Hayak, F.A. (2016/1960), “A case for freedom”, The Essential F.A. Hayek, The Foundation for Economic Education, Atlanta, GA, Originally published as "The case for freedom" in The Constitution of Liberty, The University of Chicago Press.

Helbling, M., Reeskens, T. and Wright, M. (2016), "The mobilisation of identities: a study on the relationship between elite rhetoric and public opinion on national identity in developed democracies", Nations and Nationalism, Vol. 22 No. 4, pp. 744-767, doi: 10.1111/nana.12235.

Hipsher, S. (2006), "Re-evaluation of underlying assumptions and refocusing of objectives in criticisms of international business", Critical Perspectives on International Business, Vol. 2 No. 2, pp. 114-127, doi: 10.1108/17422040610661299.

Hipsher, S. (2010), Business Practices in Southeast Asia: An Interdisciplinary Analysis of Theravada Buddhist Countries, Routledge, London.

Hipsher, S. (2016), "Private sector firms, social responsibility and poverty reduction: evidence from Cambodia”, Annals in Social Responsibility, Vol. 2 No. 1, pp. 83-98, doi: 10.1108/ASR-10-20150011.

Hipsher, S. (2018), "Human rights, poverty reduction, opportunities and the multinational enterprise", in Hipsher, S. (Ed.), Examining the Private Sector's Role in Wealth Creation and Poverty Reduction, IGI International, Hersey, PA, pp. 1-28, doi: 10.4018/978-1-5225-3117-3.ch001.

Hipsher, S. (2019), "Increased equality of opportunity through international tourism”, Journal of Global Responsibility, Vol. 10 No. 4, pp. 339-354, doi: 10.1108/JGR-04-2019-0045.

Hipsher, S. (2020), The Wealth Creation Approach to Poverty Reduction, Palgrave Macmillan, Singapore.

Hoekman, B. and Nelson, D.R. (2018), "Reflecting on populism and the economics of globalization", Journal of International Business Policy, Vol. 1 Nos 1/2, pp. 34-43, doi: 10.1057/s42214-018$0003-2$.

Hofman, K. (2008), "Placing enterprise and business thinking at the heart of the war on poverty", in Easterly, W. (Ed.), Reinventing Foreign Aid, MIT Press, Cambridge, MA. pp. 485-502.

International Labour Organization (2016), Global Wage Report 2016/17: wage Inequality in the Workplace, ILO Publications, Geneva.

International Monetary Fund (2020), World Economic Outlook Update: June 2020, IMF.

Karnani, A. (2010), "Failure of the libertarian approach to reducing poverty", Asian Business and Management, Vol. 9 No. 1, pp. 5-21, doi: 10.1057/abm.2009.20.

Khalidi, R. (2018), "Nation and class: generations of Palestinian liberation”, Rethinking Marxism, Vol. 30 No. 3, pp. 368-392, doi: 10.1080/08935696.2018.1525967.

Kobrin, S.J. (2009), "Private political authority and public responsibility: transnational politics, transnational firms, and human rights", Business Ethics Quarterly, Vol. 19 No. 3, pp. 349-374. 
Kobrin, S.J. (2019), "Make internationalism great again: the AIB in an age of populist nationalism", Academy of International Business Insights, Vol. 19 No. 1, pp. 12-15.

Kolk, A., Rivera-Santos, M. and Rufin, C. (2018), "Multinationals, international business, and poverty: a cross-disciplinary research overview and conceptual framework", Journal of International Business Policy, Vol. 1 Nos 1/2, pp. 92-115, doi: 10.1057/s42214-018-0004-1.

Korontzis, T. (2013), "Corporate social responsibility: impact of corporations on our lives", European Scientific Journal, Vol. 9 No. 22, pp. 301-308.

Krier, D. and Worrell, M.P. (2017), "The social ontology of capitalism: an introduction”, in Krier, D. and narratives Worrell, M.P. (Eds), The Social Ontology of Capitalism, Palgrave Macmillan, New York, NY, pp. 1-11.

Krugman, P. (2020), "The case for permanent stimulus”, in Baldwin, R. and Weder di Mauro, B. (Eds), Mitigating the COVID Economic Crisis: Act Fast and Do Whatever It Takes, CEPR Press, London, pp. 213-219.

Lal, D. (2013), Poverty and Progress: Realities and Myths about Global Poverty, Cato Institute, Washington, DC.

Latif, K.F. and Sajjad, A. (2018), "Measuring corporate social responsibility: a critical review of survey instruments", Corporate Social Responsibility and Environmental Management, Vol. 25 No. 6, pp. 1174-1197, doi: 10.1002/csr.1630.

Lee, J. (2020), “Beyond 2020: Indo-Pacific strategy under a democrat white house”, ISEAS Perspective, 2020-33.

Li, S. and Gaur, A. (2014), "Financial giants and moral pygmies? Multinational corporations and human rights in emerging markets", International Journal of Emerging Markets, Vol. 9 No. 1, pp. 11-32, doi: 10.1108/IJoEM-09-2013-0143.

Mason, P. (2019), "Clear bright future: a radical defence of the human being", London School of Economics Public Event Podcast, Podcast available at: www.lse.ac.uk

Menon, J. (2020), “COVID-19: balancing the infection and the misery curves”, ISEAS Perspective, 2020-64.

Milanovic, B. (2013), "Global income inequality in numbers: in history and now", Global Policy, Vol. 4 No. 2, pp. 198-208, doi: 10.1111/1758-5899.12032.

Milanovic, B. (2016), Global Inequality: A New Approach for the Age of Globalization, Harvard University Press.

Milanovic, B. (2017), "The evolution of global inequalities: the impact on politics and the economy," London School of Economics Public Lecture Series, Podcast available at: www.lse.ac.uk

Milanovic, B. (2019), "The global distribution of income and the politics of Globalisation - Embedded liberal capitalism," London School of Economics Public Lecture Series, Podcast available at: www.lse.ac.uk

Miller, T., Kim, A.B. and Roberts, J.M. (2019), 2019 Index of Economic Freedom, Heritage Foundation, Washington, DC.

Minefee, I., Neuman, E.J., Isserman, N. and Leblebici, H. (2015), "Corporate foundations and their governance", Annals in Social Responsibility, Vol. 1 No. 1, pp. 57-75, doi: 10.1108/ASR-12-2014-0005.

Mokyr, J. (2017), A Culture of Growth: The Origins of the Modern Economy, the Graz Schumpeter Lectures, Princeton University Press.

Morsy, H. Balma, L. and Mukasa, A.N. (2020), “Not a good time': economic impact of COVID-19 in Africa”, African Development Bank Working Paper, 338 (June 26).

O'Rourke, K.H. (2018), "Economic history and contemporary challenges to globalization", Nation Bureau of Economic Research [NBER] Working Paper Series, No. 25364.

Odendahl, C. and Springford, J. (2020), "Bold policies needed to counter the Coronavirus recession”, in Baldwin, R. and Weder di Mauro, B. (Eds), Mitigating the COVID Economic Crisis: Act Fast and Do Whatever It Takes, CEPR Press, London, pp. 145-150. 


\section{REPS \\ 6,1}

Okokhere, F.O. (2018), “A critical analysis of poverty reduction strategies in postcolonial Africa”, in Falola, T. and Oday, M.O. (Eds), Poverty Reduction Strategies in Africa, Routledge, London, pp. 120-136.

Orlitzky, M. (2015), “The politics of corporate social responsibility or: why Milton Friedman has been right all along", Annals in Social Responsibility, Vol. 1 No. 1, pp. 5-29, doi: 10.1108/ASR-06-2015-0004.

Piketty, T. (2014), Capital in the Twenty-First Century (Translated by Arthur Goldhammer), The Belknap Press of Harvard University Press.

Posen, A.S. (2020), "Containing the economic nationalist virus through global coordination", in Baldwin, R. and Weder di Mauro, B. (Eds), Mitigating the COVID Economic Crisis: Act Fast and Do Whatever It Takes, CEPR Press, London, pp. 203-211.

Powell, B. (2014), Out of Poverty: Sweatshops in the Global Economy, Cambridge University Press.

Powell, J. (1994), "Self-determination through unilateral free trade", in Bandow, D. and Vasquez, I. (Eds), Perpetuating Poverty: The World Bank, the IMF, and the Developing World, Cato Institute, Washington, DC DC, pp. 337-350.

Prahalad, C.K. (2005), Fortune at the Bottom of the Pyramid: Eradicating Poverty through Profits, Wharton School Publishing, Philadelphia PA.

Rangan, S. (2018), "Introduction: capitalism beyond mutuality?”, in Subramanian, R. (Ed.), Capitalism beyond Mutuality? Perspectives Integrating Philosophy and Social Science, Oxford University Press, pp. 1-22.

Ravallion, M. (2016), The Economics of Poverty: History, Measurement and Policy, Oxford University Press, New York, NY.

Resnick, D. and van de Walle, N. (Eds) (2013), "Introduction: why aid and democracy? Why Africa?", Democratic Trajectories in Africa: Unravelling the Impact of Foreign Aid, Oxford University Press, New York, NY, pp. 1-27.

Reuter, C., Foerstl, K., Hartman, E. and Blome, C. (2010), "Sustainable global supplier management: the role of dynamic capabilities in achieving competitive advantage", Journal of Supply Chain Management, Vol. 46 No. 2, pp. 45-63, doi: 10.1111/j.1745-493X.2010.03189.x.

Rittel, H. and Webber, M. (1973), "Dilemmas in a general theory of planning”, Policy Sciences, Vol. 4 No. 2 , pp. 155-169.

Rodrik, D. (2018), "Populism and the economics of globalization", Journal of International Business Policy, Vol. 1 Nos 1/2, pp. 12-33, doi: 10.1057/s42214-018-0001-4.

Rosen, G. (1982), "Gandhian economics: a Schumpetarian perspective”, Journal of Economic Issues, Vol. 16 No. 2, pp. 435-438.

Sachs, J. (2005), The End of Poverty: Economic Possibilities for Our Time, The Penguin Press, New York, NY.

Scheidel, W. (2017), The Great Leveler: Violence and the History of Inequality from the Stone Age to the Twenty-First Century, Princeton University Press.

Sen, A. (2002), "Globalization, inequality and global protest", Development, Vol. 45 No. 2, pp. 11-16, doi: 10.1057/palgrave.development.1110341.

Shiller, R. (2020), "Narrative economics," London School of Economics Public Event Series, Podcast available at: www.lse.ac.uk

Shiller, R. (2019), Narrative Economics: How Stories Go Viral and Drive Major Economic Events, Princeton University Press.

Siddiqui, J. and Uddin, S. (2016), "Human rights disasters, corporate accountability and the state", Accounting, Auditing and Accountability Journal, Vol. 29 No. 4, pp. 679-704, doi: 10.1108/AAAJ07-2015-2140.

Smith, M. (2015), "Tourism and cultural change”, in Hall, C.M., Gossling, S. and Scott, D. (Eds), The Routledge Handbook of Tourism and Sustainability, Routledge, London, pp. 175-184. 
Son, H.H. (2010), "A multi-country analysis of achievements and inequalities in economic growth and standards of living", Asian Development Review, Vol. 27 No. 1, pp. 1-42.

Sowell, T. (2015), Wealth, Poverty and Politics: An International Perspective, Basic Books, New York, narratives NY.

Srinivasan, T.N. (2013), “Trends and impacts of real and financial globalization in the People's Republic Of China and India since the 1980s", Asian Development Review, Vol. 30 No. 1, pp. 1-30.

Stifel, D. and Woldehanna, T. (2016), "Poverty in Ethiopia, 2000-11: welfare improvements in a changing economic landscape", in Arndt, C., McKay, A. and Tarp, F. (Eds), Growth and Poverty in Sub-Saharan Africa, Oxford University Press, pp. 43-68.

Tomasello, M. (2008), Origins of Human Communication, MIT Press, Cambridge, MA.

Vandenberg, P. (2017), "Can trade help achieve the employment targets of the sustainable development goals?", Asian Development Bank Institute (ADBI) Working Paper, 650.

Verbecke, A., Courudureroy, R., Matt, T. (2018), "The future of international research on corporate globalization that never was...", Journal of International Business Studies, Vol. 49 No. 9, pp. 1101-1112, doi: 10.1057/s41267-018-0192-2.

Wallerstein, I. (2013), "Structural crisis, or why capitalists may no longer find capitalism rewarding", in Wallerstein, I., Collins, R., Mann, M., Derluguian, G. and Calhoun, C. (Eds), Does Capitalism Have a Future?, Oxford University Press, pp. 9-36.

Wei, S.J. (2020), "Ten keys to beating back COVID-19 and the associated economic pandemic", in Baldwin, R. and Weder di Mauro, B. (Eds), Mitigating the COVID Economic Crisis: Act Fast and Do Whatever It Takes, CEPR Press, London, pp. 71-76.

World Bank (2018), Poverty and Shared Prosperity 2018: Piecing Together the Poverty Puzzle, World Bank Publications, Washington, DC.

World Bank (2020), Poverty and Shared Prosperity 2020: Reversals of Fortune, World Bank, Washington, DC, doi: 10.1596/978-1-4648-1602-4.

Wyplosz, C. (2020), "So far, so good: and now don't be afraid of moral hazard", in Baldwin, R. and Weder di Mauro, B. (Eds), Mitigating the COVID Economic Crisis: Act Fast and Do Whatever It Takes, CEPR Press, London, pp. 25-30.

Yan, K. (2016), Poverty Alleviation in China: A Theoretical and Empirical Study, Springer, Heidelberg.

Yang, A. and Liu, W. (2018), "Corporate environmental responsibility and global online cross-sector alliance network: a cross-national study", Environmental Communication, Vol. 12 No. 1, pp. 90-114, doi: 10.1080/17524032.2016.1249900.

Yarbrough, C.D. (2016), "Mary's magnificat: the Anawim and Church on the margins", in Kollar, N.R. and Shafiq, M. (Eds), Poverty and Wealth in Judaism, Christianity, and Islam, Palgrave Macmillan, New York, NY, pp. 55-73.

Yunus, M. and Weber, K. (2007), Creating a World without Poverty: Social Business and the Future of Capitalism, Public Affairs, New York, NY.

\section{Corresponding author}

Scott Allen Hipsher can be contacted at: scotta_1998@yahoo.com

For instructions on how to order reprints of this article, please visit our website:

www.emeraldgrouppublishing.com/licensing/reprints.htm

Or contact us for further details: permissions@emeraldinsight.com 